\title{
Socio-economic and socio-legal aspects of labor market regulation in modern Russia
}

\author{
Oleg Muratovich Epkhiev ${ }^{1}$ and Anatolii Sergeevich Kislyakov \\ Financial University under the Government of the Russian Federation, Department of Sociology, \\ Moscow, Russia
}

\begin{abstract}
The object of this study is the problem of market regulation in modern Russia. The author has set a goal based on a comprehensive system analysis of the Russian Federation's scientific works and normative legal documents to uncover and characterize the socio-economic and socio-legal aspects of the problems of regulating the labor market at the federal and regional levels. In his work, the author relied not only on solidarizing but also on alternative theoretical approaches and conclusions. The scientific results obtained in the course of the study allowed us to understand and substantiate that at the federal and regional levels, the Russian Federation requires a very serious adjustment of institutional mechanisms for regulating the labor market, on which the development of its economy depends. The scientific novelty of the work lies in the conclusion that in current conditions, Russia should provide more in-depth fundamental research of the labor market, which would contribute to the formation of more effective public policy in the regulation of the labor market, employment of the population. This will entail the need to develop the implementation of social, economic, industrial policy, considering its impact on the labor market.
\end{abstract}

Keywords: labor market, Russia, state, employee

\section{Introduction}

Problems of functioning of the labor market, which can have a very negative impact on the situation in the social sphere of any state, naturally, at all times, have interested both science and the government, almost all states seeking to regulate it through certain economic, social, legal mechanisms. Suffice it to recall that as early as 1905, the British Parliament, in resolving the problems of employment, wage labor, including unemployment, passed the Unemployment Act, under which organizations were created in the industrialized cities of England, with the tasks of labor exchanges and statistical committees [1]. In 1911, the National Insurance Act was adopted, which provided compulsory unemployment insurance for workers over 18. The fund for insurance benefits was made up of contributions from the state, businessmen, and workers.

${ }^{1}$ Corresponding author: OMEpkhiev@fa.ru 
In 1935, the United States passed the Labor Relations Act (Wagner Act), which enshrined workers' rights and labor unions. The Law on Social Insurance, adopted in the same year, provided social support measures for the unemployed and certain categories of employed citizens. Solving the employment problems and the labor market in 1946, the US Congress passed the Employment Act. As part of the anti-poverty program, laws were passed in the 1960s that were also designed to reduce social tensions in society and stimulate economic growth by providing high levels of employment and consumption, which in our view, laid the foundation for the mass consumption society [2].

It is believed that the labor market in Russia began to form much later than in Western Europe and the United States and refers to the period of the Great Reforms implemented by Alexander II in 1860-1870. In February 1861, Alexander II signed the Manifesto on the Abolition of Serfdom and the Statute on Peasants Departing from Serfdom, which consisted of 17 legislative acts that defined and regulated the issues of the liberation of peasants, the redemption of land by liberated peasants [3]. With the emergence of the working class and its growth, especially during the Peasant Reform or the abolition of serfdom, Russian cities became major industrial centers with a new labor market [4].

The history of the Russian labor market is very rich and of particular scientific interest since its development was influenced by different social systems. The interest in practical terms stems from the need for the state, as the main regulator of the labor market, effective measures of its regulation to achieve equilibrium.

At present, the state of the labor market as one of the most important conditions for the socio-economic stability of society is determined by many economic, demographic, political, legal, and other factors. Furthermore, if in economic science, economic theories, the labor market are considered only in the aspect of the relationship between the employer and the employee, selling their professional skills and competencies, sociology is more productive in its studies of the problem because of the multidimensional approach.

The study of the labor market in sociology has given rise to a special scientific tradition of considering it at both the organizational and social levels of society and, importantly, at the institutional level. The importance of the institutional approach in the study of labor market problems is obvious. It suggests a special focus of research attention on the social nature, content, factors, and in a sense, social process, considering the labor market as a system, primarily, social interrelations and relationships arising in this market between its main participants.

\section{Methods}

The base of sources was composed with a retrospective approach, which allowed to trace the evolution, since the mid-twentieth century, of labor market regulation in Russia and other foreign countries and to identify the main variables related to the subject of research. The methodological basis of the study was a system-complex approach of scientific papers [1-23], normative legal documents [24-27], which allowed to identify and substantiate the need to regulate the labor market in Russia. The epistemological potential of statistical and sociological methods of quantitative and qualitative research gave the opportunity to adequately interpret the results of scientific research on the subject of analysis. The novelty of the work and its results are determined by an original approach to identifying the characteristic features that reveal the socio-economic and socio-legal aspects of market regulation in Russia. 


\section{$3 \quad$ Results and discussion}

The system-forming elements or subjects of the labor market are the state, the employee, and the employer. The labor market is a very important element of the state's economic system; if so, the state's primary task should undoubtedly be to regulate this market. The regulation of the labor market can and should be seen as a specific sector of the regulatory impact of the state on social and economic processes in society. State participation in the regulation of the labor market should be aimed at achieving a high level of employment; ensuring the most reasonable compliance of specialists' training with the structure of necessary jobs; leveling the effects of unemployment; creating sufficient and necessary social, economic, legal conditions for the functioning of workers. In essence, the achievement of an optimal social and economic state of the labor market, its stability and balance should be characterized by a combination of such factors as employment, decent wages, the implementation of measures stipulated by law for the social protection of workers in case of suspension of production or dismissal of workers, development, and implementation of measures to preserve and use the professional potential of workers, their social protection, improving working conditions and a number of other issues creating sufficient and necessary conditions for the balance of the labor market and the implementation of social stability policies in society. In modern Russia, the following regulatory components established by law can be distinguished:

1. The minimum wage, the size of which is established by the Federal Law "On the minimum wage". Since 2021, the ratio of the minimum wage and the median wage is set at $42 \%$. The median wage is a value that divides all workers into two equal parts: half of the workers have wages higher than this amount, and the other half have lower wages. This indicator can be calculated on the scale of the entire state and separately in the region, locality, and even in individual enterprises or their structural divisions. This ratio is subject to revision at least once every 5 years based on the state's socio-economic development conditions. However, the minimum wage for the next year is not lower than the minimum subsistence level of the able-bodied population in the Russian Federation for the next year and not lower than the minimum wage set for the current year. Calculation of the median wage is based on the methodology determined by Rosstat.

Table 1. Federal minimum wage values in 2017-2021.

\begin{tabular}{|l|c|c|c|c|c|c|}
\hline $\begin{array}{l}\text { Date of the } \\
\text { minimum } \\
\text { wage } \\
\text { introduction }\end{array}$ & 1.07 .2017 & 1.01 .2017 & 1.01 .2018 & 1.01 .2019 & 1.01 .2020 & 1.01 .2021 \\
\hline $\begin{array}{l}\text { Minimum } \\
\text { wage } \\
\text { amount, } \\
\text { RUB }\end{array}$ & 7,800 & 9,489 & 11,163 & 11,280 & 12,130 & $\begin{array}{c}12,792 \\
\text { (new } \\
\text { metrics) }\end{array}$ \\
\hline
\end{tabular}

2. The consumer price index for goods and services serves as the basis for a systematic increase in the monetary income of the population. This is a type of index created to measure the average level of change in prices of goods and services over a certain period. The consumer price index (CPI) is calculated following the official statistical methodology of the organization of statistical monitoring of consumer prices for goods and services and the calculation of consumer price indices, approved by order of Rosstat No. 734 dated December 30, 2014. It is an objective socio-economic indicator 
calculated to measure changes over time in the general level of prices for consumer goods and services purchased for household consumption.

Table 2. Consumer price and tariff indices for goods and services.

\begin{tabular}{|c|c|c|c|c|c|c|c|c|c|}
\hline \multicolumn{3}{|c|}{ Total } & \multicolumn{9}{|c|}{ Including } \\
\cline { 4 - 9 } & $\begin{array}{c}\text { To the } \\
\text { previous } \\
\text { period }\end{array}$ & $\begin{array}{c}\text { By } \\
\text { December } \\
\text { of the } \\
\text { previous } \\
\text { year }\end{array}$ & $\begin{array}{c}\text { To the } \\
\text { previous } \\
\text { period }\end{array}$ & $\begin{array}{c}\text { By } \\
\text { December } \\
\text { of the } \\
\text { previous } \\
\text { year }\end{array}$ & $\begin{array}{c}\text { To the } \\
\text { previous } \\
\text { period }\end{array}$ & $\begin{array}{c}\text { By } \\
\text { December } \\
\text { of the } \\
\text { previous } \\
\text { year }\end{array}$ & $\begin{array}{c}\text { To the } \\
\text { previous } \\
\text { period }\end{array}$ & $\begin{array}{c}\text { By } \\
\text { December } \\
\text { of the } \\
\text { previous } \\
\text { year }\end{array}$ \\
\hline Q1 & 101.3 & 101.3 & 102.2 & 102.2 & 100.8 & 100.8 & 100.7 & 100.7 \\
\hline Q2 & 101.3 & 102.6 & 102.1 & 104.3 & 101.0 & 101.8 & 100.7 & 101.4 \\
\hline Q3 & 100.2 & 102.9 & 98.8 & 103.1 & 101.3 & 103.1 & 100.9 & 102.4 \\
\hline Q4 & 102.0 & 104.9 & 103.5 & 106.7 & 101.7 & 104.8 & 100.3 & 102.7 \\
\hline & & & $\mathbf{2 0 2 0}$ & & & \\
\hline Q1 & $\mathbf{1 0 2 . 1}$ & $\mathbf{1 0 2 . 1}$ & $\mathbf{1 0 3 . 1}$ & $\mathbf{1 0 3 . 1}$ & $\mathbf{1 0 1 . 8}$ & $\mathbf{1 0 1 . 8}$ & $\mathbf{1 0 1 . 2}$ & $\mathbf{1 0 1 . 2}$ \\
\hline
\end{tabular}

Importantly, among other things, the CPI is also used to regulate wages and social security, and other benefits to partially or fully compensate for changes in the cost of living or consumer prices.

3. The Unified Rate Schedule for Employees was introduced by RF Government Decree No. 785 of October 14, 1992, "On differentiation of wages in the public sector based on the Unified Rate Schedule". It is a system of grades that determines the correlation between wages and qualification level of work of employees of the budgetary sphere. Consists of 18 grades dividing all types of work performed in organizations into 18 "types", depending on the level of qualification and degree of complexity. There are norms in current Russian labor law that provide for increased payment for difficult and hazardous working conditions. For example, extra pay for night work, overtime, work in the Far North and equivalent areas, other benefits and guarantees, and compensation for wages.

4. Norms of compensation for delayed wage payments. If the employer violates the deadlines for payment of wages, vacation pay, termination payments, and other payments to the employee, the employer must pay them with interest in an amount not less than one hundred and fifty percent of the key rate of the Central Bank of Russia in effect at that time. If wages and other payments to an employee are not paid on time, the interest on monetary compensation is calculated from the amounts not paid on time. The monetary compensation paid to an employee may be increased by a collective agreement, a local normative act, or an employment contract. The obligation to pay this monetary compensation arises regardless of the fault of the employer [25].

A very radical revision of institutional instruments of regulation of the modern Russian labor market is required, and the importance of this issue lies, above all, in the fact that the solution of this issue very seriously depends on the development of the socio-economic sphere of society.

The thing is that the improvement and development of socio-economic and socio-legal mechanisms of labor market regulation require the development and implementation of 
social, industrial, demographic, and other policies in terms of their impact on employment, with a reorientation from the solution of current problems to the development and implementation of important strategic directions of development and acceleration, while the process of forming a civilized competitive environment in the domestic market, given the real growing trends of digitalization of the economy, crisis trends both in the global economy and in the country, which in addition to other well-known factors are also caused by restrictive measures associated with pandemics, the varying level of socio-economic development of Russian regions, etc.

This gives us every reason to believe that today's Russian labor market is a systemic phenomenon. Therefore, the very concept, its essence, content, factors, and conditions of implementation of real mechanisms of regulation of modern Russian labor market refer to the key; we can say fundamental theoretical and practical research problems of such scientific directions as economic sociology, law, economics and of course, political science.

It is obvious that without strategic planning of the country's socio-economic development, a systematic approach to the regulation of the labor market, it is extremely difficult and impossible to talk about the development of economic, social, and political sectors of society and the state. Therefore, the formation and development of real labor market mechanisms, although not sufficient, is seen in modern Russia's state policy. For example, in 2008, the Russian government approved a Labor Market Action concept for 2008-2010 by its order in August 2008. Priority tasks of labor market development were the implementation of investment and innovation projects in high-tech areas of the economy; formation and development of production clusters, as well as the development of energy, industry, and transport infrastructure; development and modernization of education, health, housing, and agro-industrial complex; creation and improvement of market institutions, as well as the development of small entrepreneurship [26]. In November of the same year, 2008, the Government of the Russian Federation approved the Concept of long-term economic development of the Russian Federation for the period till 2020, where the development of the labor market section defines the goal of the state policy in the development of the labor market in the long-term perspective, which comes down to the creation of legal, economic and institutional conditions providing the development of flexible efficiently functioning labor market that allows to overcome the structural discrepancy between the labor supply and demand, to decrease the share of illegal employment, to increase the share of illegal employment.

In addition to the above factors of the labor market, it is obvious that in a market economy, the market mechanism of labor market regulation includes two important elements: the demand for labor and, of course, supply and the labor price on the labor market. The level of correlation between labor demand and supply on the market determines the real state of the labor market, its structure, and equilibrium.

If the essential understanding of the labor market in a broad sense is reduced and accepted as a system of relations between the employer, the employee, and the state, and related to these relations the whole system of socially important aspects, it is quite natural that the question of legal regulation of the labor market arises. No less important for deeper scientific understanding and practical implementation is the question of the functional structure of the modern Russian labor market, given such current global trends as globalization of the economy, the intensification of the process of convergence of economic relations and relations at the regional level, digitalization of the economy, sanctions wars, pandemics. Under these conditions, a well-considered state policy is required in crucial issues related to promoting and stimulating employment growth; the social partnership between employers, workers, and the state; ensuring competition in the labor market among 
both employers and workers; setting wage rates that would be equitable; and implementing effective social support measures for the unemployed.

Obviously, in regulating the labor market, the state must play and plays a special role, and the issues of legal regulation are laid down and permeate almost all the legal fields of modern Russian society and have their enforcement in the Constitution of the Russian Federation, international legal documents, the Labor Code, the Administrative Code of the Russian Federation and certainly in the Criminal Code, as well as in the decrees of the President of the Russian Federation, resolutions and orders of the Russian Government, industry and departmental regulations, laws and other regulatory legal acts of the Russian Federation. The basic principles of contemporary Russian state policy in employment promotion are set forth by law in Articles 7 and 37 of the Constitution of the Russian Federation, which states that "The Russian Federation is a social state, the policy of which is aimed at creating conditions that provide a decent life and free development of man... labor and health of people are protected, a guaranteed minimum wage is established...". [24].

The main national legal act in employment promotion and employment is the Law of the Russian Federation of April 19, 1991. No. 1032-1 "On employment of the population in the Russian Federation", which defines the economic and organizational foundations of the state policy in the field of population employment. The law on employment allows to establish economic and legal forms and methods of regulating employment relations (status of the unemployed, employment fund), to develop a system of social support: payment of temporary unemployment benefits and material assistance to disabled family members. Moreover, in March 2021, the Government adopted Decree No 362 of March 13, 2021, "On government support in 2021 to legal entities and individual entrepreneurs in job placement of unemployed citizens", which established rules for providing subsidies in 2021 to legal entities and individual entrepreneurs to stimulate job placements for unemployed citizens.

\section{Conclusion}

Thus, a rather brief description of the problem of socio-economic and socio-legal aspects of labor market regulation in modern Russia allows coming to understand that a very serious adjustment of institutional mechanisms of labor market regulation, on which economic development depends, is required at the federal and regional levels. In current conditions in Russia should provide more in-depth fundamental research of the labor market, which would contribute to the formation of more effective public policy in regulating the labor market and the employment of the population. This will entail the need to develop the implementation of social, economic, industrial policy, considering its impact on the labor market.

\section{References}

1. F.A. Rothstein, Ocherki po istorii rabochego dvizheniya v Anglii [Essays on the history of the labor movement in England] (State Publishing House, Moscow, Leningrad, 1925)

2. O.A. Zhidkov, N.A. Krasheninnikova, V.A. Saveliev, [Istoriya gosudarstva i prava zarubezhnykh stran, Chast 2] History of the state and law of foreign countries, Part 2 (Norma Publishing House, Moscow, 1996) 
3. B.N. Mironov, Sotsialnaya istoriya Rossii v period Imperii (18 - nachalo 20 veka): Genezis lichnosti, Demokratii, Semi, Grazhdanskogo obshchestva i pravovogo gosudarstva [Social History of Russia during the Empire period (18th - early 20 century): Genesis of Personality, Democracy, Family, Civil Society and Legal State] (St. Petersburg, 2003)

4. V.S. Ilyin, Promyshlennoe razvitie Rossii s kontsa 19 veka do nachala stalinskogo "Velikogo perelomnogo momenta" [Industrial development of Russia from the end of the 19th century to the beginning of Stalin's "Great turning point"], in Collection of scientific works of the Peoples' Friendship University of Russia (Moscow, 2004)

5. Yu.P. Mador, Podem rabochego dvizheniya v Anglii v 1910-1913 godakh [The rise of the labor movement in England in 1910-1913] (Moscow, 1966)

6. P.A. Zayonchkovsky, Otmena krepostnogo prava v Rossii [The abolition of serfdom in Russia] (Moscow, 1954)

7. S. Baert, Discrimination in the labor market: a register of (almost) all correspondence experiments since 2005, in S.M. Gaddis (ed), Audit Studies: Behind the Scenes with Theory, Method, and Nuance, 63-77 (Springer, 2018)

8. S. Baert, B. Cox, N. Gheyle, C. Vandamme, Ind. Labor Relat Rev, 68, 467-500 (2015)

9. H. Blumer, Pac Socio Rev, 1, 3-7 (1958)

10. E. Bonacich, Am Socio Rev, 37(5), 547-559 (1972)

11. G.J. Borjas, Am Econ Rev, 77, 531-553 (1987)

12. F. Dobbin, et al., Am J Sociol, 99, 396-427 (1993)

13. D. Acemoglu, Rev Econ Stud, 64(3), 445-464 (1997)

14. W. Arulampalam, A.L. Booth, Brit J Indust Rel, 36(4), 521-536 (1998)

15. P. Cahuc, F.vPostel-Vinay, Labor Econ, 9(1), 63-91 (2002)

16. C. Dustmann, U. Schönberg, Rev Econ Stat, 91(2), 363-376 (2009)

17. H. Hopenhayn, R. Rogerson, J Polit Econ, 101(5), 915-938 (1993)

18. M. Picchio, J.C. van Ours, Labor Econ, 18(5), 712-722 (2011)

19. O. Åslund, D.O. Rooth, Econ J, 117(518), $422-448$ (2007)

20. M. Barrett, Gender and the division of labor Women's oppression today, in The Marxist/feminist encounter, 152-186 (Verso Books, 2014)

21. D. Bhugra, M.A. Becker, World Psychiatry, 4(1), 18 (2005)

22. I. Kogan, M. Weißmann, Adv Life Course Res, 18(3), 185-198 (2013)

23. K.I. Paul, K. Moser, J Vocat Behav, 74(3), 264-282 (2009)

24. Konstitutsiya Rossiiskoi Federatsii (prinyata vsenarodnym golosovaniem $12.12 .1993 \mathrm{~s}$ izmeneniyami, odobrennymi v khode obshcherossiiskogo golosovaniya 01.07.2020) [The Constitution of the Russian Federation (adopted by popular vote on 12.12.1993 with amendments approved during the all-Russian vote on 01.07.2020)]. Accessed on: October 14, 2021. [Online]. Available: http://www.consultant.ru/document/cons_doc_LAW_28399/

25. Trudovoi kodeks Rossiiskoi Federatsii ot 30.12.2001 No. 197-FZ (red. ot 28.06.2021, s izm. of 06.10.2021) (s izm. i dop., vstup. v silu s 01.09.2021) [Labor Code of the Russian Federation dated 30.12.2001 No. 197-FZ (ed. dated 28.06.2021, with amendments. from 06.10.2021) (with amendments and additions, intro. effective from 
01.09.2021)], 236. Accessed on: October 14, 2021. [Online]. Available:

http://www.consultant.ru/document/cons_doc_LAW_34683/

26. Pravitelstvo Rossiiskoi Federatsii, Rasporyazhenie ot 15 avgusta 2008 g. No. 1193-r "Kontseptsiya deistvii na rynke truda na 2008-2010 gody" [The Government of the Russian Federation, Decree No. 1193-r of August 15, 2008 "The concept of actions in the labor market for 2008-2010"]. Accessed on: October 14, 2021. [Online]. Available: http://www.consultant.ru/document/cons_doc_LAW_79451/c28e8ae3291ba6db7098c2 057be342fae6b5ca41/

27. Rasporyazhenie Pravitelstva RF ot 17.11.2008 No. 1662-r (red. ot 28.09.2018) “O Kontseptsii dolgosrochnogo sotsialno-ekonomicheskogo razvitiya Rossiiskoi Federatsii na period do 2020 goda" (vmeste s "Kontseptsiei dolgosrochnogo sotsialno-ekonomicheskogo razvitiya Rossiiskoi Federatsii na period do 2020 goda") [Decree of the Government of the Russian Federation of 17.11.2008 No. 1662-r (ed. of 28.09.2018) "On the Concept of long-term socio-economic development of the Russian Federation for the period up to 2020" (together with the "Concept of long-term socio-economic development of the Russian Federation for the period up to 2020")]. Accessed on: October 14, 2021. [Online]. Available: http://www.consultant.ru/document/cons_doc_LAW_82134/ 